\title{
Studies on Populations of Lutzomyia longipalpis (Lutz \& Neiva, 1912) (Diptera: Psychodidae: Phlebotominae) in Brazil
}

\author{
Alfredo CR de Azevedo/ ${ }^{+}$, Fernando A Monteiro*, Pedro H Cabello**, \\ Nataly A de Souza, Maria Goreti Rosa-Freitas***, Elizabeth F Rangel
}

\begin{abstract}
Departamento de Entomologia **Departamento de Genética ***Departamento de Bioquímica e Biologia Molecular, Instituto Oswaldo Cruz, Av. Brasil 4365, 21045-900 Rio de Janeiro, RJ, Brasil *Departamento de Genética, Universidade Federal do Rio de Janeiro, Cidade Universitária, 21941-590 Rio de Janeiro, RJ, Brasil
\end{abstract}

Studies were performed on five Brazilian populations of Lutzomyia longipalpis: Salvaterra (PA), São José do Ribamar (MA), Canindé (CE), Natal (RN) and Gruta da Lapinha, Lagoa Santa (MG). No morphological differences were observed that could distinguish between these populations. Homogeneity tests showed that the allopatric populations display a certain heterogeneity and that the sympatric populations, with different patterns of spots, are homogeneous. The Student-Newman-Keuls test, represented by Euler-Venn diagrams, showed a disjunction between the populations from the north/northeast and the one from Gruta da Lapinha. Genetic distances between the four populations (excluding the Canindé population) were within the range of intrapopulational differences. The Gruta da Lapinha population displayed a heterozygotic deficiency that could be a consequence of high levels of inbreeding due to cryptic habits of living in a small cave. These results do not favor the hypothesis of a $\mathrm{L}$. longipalpis species complex in Brazil, and the species should be considered high polymorphic.

Key words: Lutzomyia longipalpis - Phlebotominae - taxonomy - morphology - Brazil

Lutzomyia longipalpis has a broad distribution in Brazil and has been recorded in North, Central, and South America, from Mexico to Argentina (Young \& Duncan 1994).

This sand fly species is considered a vector for visceral leishmaniasis, caused by Leishmania (Leishmania) chagasi, and in Brazil is frequently found associated with human dwellings and domestic animal shelters, in periurban areas, and on farms (Badaró 1995). Considering its occurrence in different geographical regions of Brazil, there may be barriers to the migration of populations. This possibility was mentioned by Mangabeira (1969), who first described morphological variations in L. longipalpis males, comparing specimens from the States of Ceará (CE) and Pará (PA) in Brazil. Males from PA had a single pair of pale spots on the fourth tergite, while those from CE had an additional pair of spots on the third tergite.

This research was supported by Papes/Fiocruz and Capes/CNPq, Brazil, and is part of the first author's MSc thesis.

${ }^{+}$Corresponding author. Fax: +55-21-290.9339. E-mail: azevedo@gene.dbbm.fiocruz.br

Received 28 Setember 1999

Accepted 24 January 2000
Mangabeira (1969) commented that these two forms could be found in different ecological habitats and suggested that they might represent two different species.

A study by Ward et al. (1985) on the distribution of two morphological forms of $L$. longipalpis indicated that males with one pair of spots have appeared from Mexico to Southern Brazil and that the two-spotted form is concentrated more in northeast Brazil. The two forms occur sympatrically in some Brazilian States: Maranhão (MA), Piauí (PI), Ceará (CE), and Rio Grande do Norte (RN). Intermediate forms occur in areas where the two forms (with one and two spots, respectively) occur sympatrically in northeast Brazil (Ward et al. 1988, Mukhopadhyay et al. 1998).

Lanzaro et al. (1993) traced the isoenzymatic profiles of populations of $L$. longipalpis reared in the laboratory, originally from Costa Rica, Colombia, and Brazil. Some 27 enzymes were assayed, and the results showed multiple genetic polymorphisms, with hybridization between populations resulting in sterile males. This finding suggested that the Costa Rican population was different from those of Brazil and Colombia. According to Warburg et al. (1994) the different clinical manifestations caused by $L$. ( $L$.) chagasi in Costa Rica, Colombia and Brazil were probably due to different concentrations of maxadilan in the saliva of 
the L. longipalpis populations. Differences were also found between the populations in the nucleotide sequence for maxadilan, revealing a polymorphism in the Costa Rican population.

Recently, Yin et al. (1999) examined microscopically the brain cells of fourth instar sandfly larvae of L. longipalpis of Brazil (Jacobina and Gruta da Lapinha), Colombia and Costa Rica. Differences of G-banding and/or position of the centromere on chromosome 4 distinguished four putative sibling species from Brazil, Colombia and Costa Rica. The karyotype of the population from Jacobina showed an apparently plesiomorphic pattern of G-banding.

Lanzaro et al. (1999) reported variation in the primary DNA and inferred amino acid sequences of maxadilan. Differences were found within and among natural field populations as well as among sibling species. Results indicated a high degree of divergence in the salivary peptide maxadilan in populations of the Brazil, Colombia and Costa Rica.

Mutebi et al. (1999) analyzed eleven populations of $L$. longipalpis from different areas of Brazil. Genotypic frequencies within populations were in close compliance to Hardy-Weinberg expectations, suggesting there are non sympatric species among these populations. The levels of genetic distance between pairs of populations were very low, consistent with local populations within a single sand fly species. Estimate of effective migration rates among all populations were low, suggesting that gene flow is restricted among populations, which is probably the reason for the observed genetic substructuring.

Other works on genetic variation and the implication on the taxonomic status of $L$. longipalpis have been extensively done with results pointing either for a single species or for a complex species (Ward et al. 1983, Lane \& Ward 1984, Lane et al. 1985, Ward et al. 1988, Lanzaro et al. 1998, Mukhopadhyay et al. 1997, 1998, Dujardin et al. 1997, Munstermann et al. 1998, Mutebi et al. 1998).

Although morphology is a traditional tool in taxonomic studies, it has been overlooked in relation to L. longipalpis, which has primarily been the target of biochemical studies. Even, species has been proposed as a possible complex of cryptic species, there is a lack of detailed knowledge of its morphological characters which might define different populations or indicate some degree of intrapopulational heterogeneity.

In order to clarify the taxonomic status of $L$. longipalpis, the current article presents the results of morphological and morphometric observations of Brazilian populations displaying different patterns of spots on the abdominal tergites. Biochemi- cal tests were also performed to complement the morphological analysis.

\section{MATERIALS AND METHODS}

Study samples - Specimens were obtained from the following areas: North Brazil - Salvaterra, Marajó Island (PA); Northeast Brazil - São José do Ribamar, São Luís Island (MA); Canindé (CE); Natal (RN); and Southeast Brazil - Gruta da Lapinha, Lagoa Santa (MG). These populations are representative of three different pale-spotted patterns (Fig. 1).

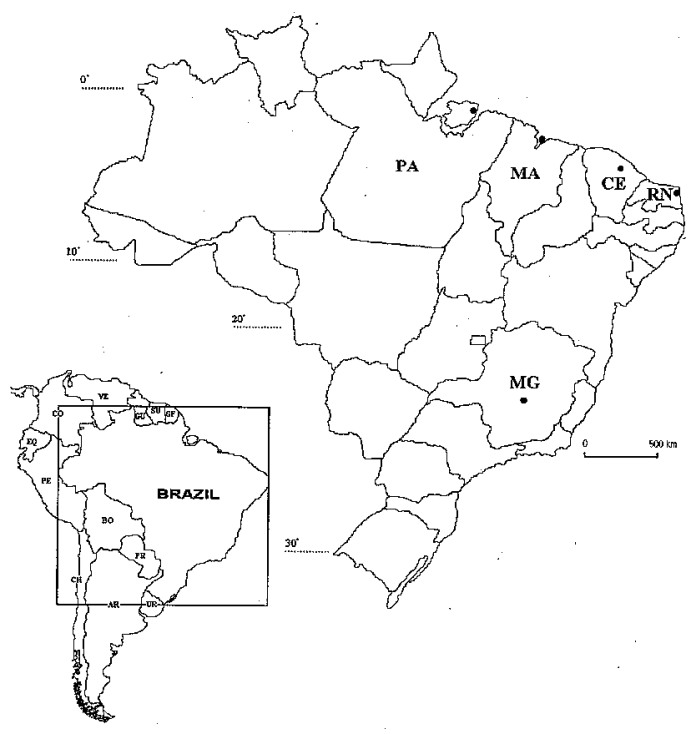

Fig. 1: localities where of Lutzomyia longipalpis specimens were collected : Pará (PA), Marajó Island, Salvaterra; Maranhão (MA), São Luís Island, São José do Ribamar; Ceará (CE), Canindé; Rio Grande do Norte (RN), Natal; Minas Gerais (MG), Lagoa Santa, Gruta da Lapinha.

Sand fly capture - Performed in peridomiciliary areas, in domestic animal shelters, using miniature CDC light traps. Specimens from Lagoa Santa were also caught in the cave at Gruta da Lapinha using CDC light traps.

Morphology and morphometry - Morphometric studies were used to verify intrapopulational homogeneity and variety among populations. In populations with different patterns of pale spots, heterogeneity was tested based on the correlation of morphometry with pale-spotted patterns. We examined 40 specimens ( 20 males and 20 females) from each site and routinely used 52 morphological and morphometric features to identify the sandflies (Young \& Duncan 1994), along with other characters recommended by the CIPA Group Computer Aided Identification of Phlebotomine Sandflies of the Americas (Bermudes et al. 1991). 
For morphometry, we measured the length and/or width of structures (Table I).

Statistical analysis - Homogeneity, parametric (Levene, ANOVA, and Student-Newman-Keuls or SNK), and non-parametric tests (Kruskall-Wallis) were applied to the populations in which different patterns of spots occurred sympatrically (MA, CE and $\mathrm{RN}$ ) and in the allopatric populations (PA, MA, $\mathrm{CE}, \mathrm{RN}$ and $\mathrm{MG})$. The SNK results were displayed graphically using Euler-Venn diagrams and interpreted according to the Intuitive Set Theory (Abe \& Papavero 1991). Tests were performed using SPSS for Windows, with a significance level of $5 \%$. When the statistical $F$ value was not significant and the variances among populations were statistically significant, the Kruskall-Wallis test was applied.
Isoenzymatic studies - Adult male sandflies captured in the field were analyzed by agarose as in Rosa-Freitas et al. (1990) and cellulose acetate as in Dujardin and Tibayrenc (1985) for allozyme gel electrophoresis. Nine enzymes were assayed for four populations (PA, MA, RN and MG): malic enzyme (ME), phosphogluconate dehydrogenase (GPD), glucose-6-phosphato isomerase (GPI), phosphoglucomutase (PGM), glicerol 3-phosphate isomerase ( $\propto-\mathrm{GPD})$, hexokinase (HK), isocitrate dehydrogenase (IDH), malate dehydrogenase $(\mathrm{MDH})$ and mannose 6-phosphate isomerase (MPI), comprising a total analysis of 10 loci, considering that two loci were scorable for the MDH enzyme. Specimens from CE population were not in enough number to allow isoenzyme analysis.

TABLE I

Morphological and morphometric characters: Lutzomyia longipalpis

\begin{tabular}{ll}
\hline Morphological & Morphometric \\
\hline Head & Male and female \\
\hline Palpal formula & Length of frontal head \\
Spines of the pharynx & Length of head \\
Striae of the pharynx & Length of labrum-epipharynx \\
Labial fork & Length of 1st, 2nd, 3rd, 4th and 5th palpal segments \\
Proximal prolongation of ascoids & Length of clipeo \\
Terminal part of proximal ascoids & Minimal distance between eyes \\
Distal prolongation of ascoids & Length of $\mathrm{F}_{1}, \mathrm{~F}_{2}, \mathrm{~F}_{13}$ and $\mathrm{F}_{14}$
\end{tabular}

Teeth of cibarium

Teeth in the lacinea (arrangement)

Number of apicolateral teeth hypopharynx

\begin{tabular}{ll}
\hline Thorax & Male and female \\
\hline Colour pronotum & Width of wing \\
Colour pre-scutum & Length of $\mathrm{R}_{5}$, alfa, beta, gama and delta veins of wing \\
Colour scutum & Length of fore, mid and hind femur \\
Colour post-scutellum & Length of fore, mid and hind tibia \\
Colour katepisternum & Length of fore, mid and hind tarsomere \\
Colour anepimeron &
\end{tabular}

Colour anepimeron

Colour katepimeron

Colour coxa

\begin{tabular}{ll}
\hline Abdomen & Male \\
\hline Pale spots on abdominal tergites & Length of coxite \\
Setae tuffs on coxite & Width of coxite \\
Number of setae of the coxite & Length of lateral lobe \\
Differentiated setae of coxite & Width of lateral lobe \\
Differentiated setae of paramere & Length of genital pump \\
Shape and setae on style & Length of piston \\
Number of spines style & Length of genital filament \\
Distribuition of insertion style spines & Length of style \\
& Distance between the setae and apical part of paramere \\
\hline & Female \\
\hline Aspect of the spermatheca body and individual ducts & Length of spermatheca body \\
Axis of spermatheca head & Width of spermatheca body \\
& Length of individual duct of spermatheca \\
\hline
\end{tabular}


Genotype frequencies were obtained directly by band counting. Based on these gene frequencies, heterozygosity estimates, fits to Hardy-Weinberg equilibrium, levels of genetic distance (D, Nei 1978), levels of inbreeding for each population $\left(\mathrm{F}_{\mathrm{IS}}\right.$, Nei 1977), and the effect of geographical subdivision on the genetic structure of the whole population $\left(\mathrm{F}_{\mathrm{ST}}\right.$, Nei 1977) were calculated using the Biosys-1 Computer Program (Swofford \& Selender 1981). Significance levels of $F_{S T}$ estimates were evaluated by the Waples (1987) chi-squared test: $\chi^{2}=2 \mathrm{NF}_{\mathrm{ST}}(\mathrm{k}-1) ; \mathrm{DF}=(\mathrm{k}-1)(\mathrm{s}-1)$, where $\mathrm{N}$ is the total number of individual sampled, $\mathrm{k}$ is the number of alleles at the locus, and $\mathrm{s}$ is the number of populations. The significance levels of $\mathrm{F}_{\mathrm{IS}}$ were evaluated according to $\mathrm{Li}$ and Horvitz (1953): $\chi^{2}=$ $\mathrm{F}_{\mathrm{IS}}{ }^{2} \mathrm{~N}(\mathrm{k}-1) ; \mathrm{DF}=\mathrm{k}(\mathrm{k}-1) / 2$. The $\mathrm{F}_{\mathrm{ST}}$ used to estimate the number of migrants $(\mathrm{Nm})$ among populations per generation (Slatkin 1987) was according to the formula: $\mathrm{F}_{\mathrm{ST}}=1 /(1+4 \mathrm{Nm})$.

\section{RESULTS}

Morphology - Using structural characters of the head, thorax, and abdomen of both sexes we could detect no significant morphological differences among the five populations studied. We calculated the percentages of qualitative and quantitative morphological characters for males and females from the population samples of $L$. longipalpis from PA, MA, RN, CE and MG (Tables II, III).

Variations occurred in the males in both the formula of the palpus and the number of spots on the abdominal tergites. The most frequent formula was 1.2.4.3.5, occurring in $100 \%$ of the specimens from the PA and CE populations. As for the number of spots on the tergites, the MG population was the only one in which we observed no variation with a constant feature of one pair of spots. This aspect was also observed in the other populations, except for MA. In the latter there was an equal proportion of the intermediate (the pair of spots on

TABLE II

Percentage of variations found in morphological characters in males Lutzomyia longipalpis from Salvaterra (Marajó Island, PA), São José do Ribamar (São Luís Island, MA), Canindé (CE), Natal (RN) and Lagoa Santa (Gruta da Lapinha, MG), Brazil

\begin{tabular}{|c|c|c|c|c|c|c|}
\hline \multirow[t]{2}{*}{ Character } & \multirow[t]{2}{*}{ Variation } & \multicolumn{5}{|c|}{$\%$} \\
\hline & & PA & MA & $\mathrm{CE}$ & $\mathrm{RN}$ & MG \\
\hline \multirow[t]{3}{*}{ Palpal formula } & 1.2.4.3.5 & 100 & 90 & 100 & 85 & 85 \\
\hline & 1.4.2.3.5 & - & - & - & 10 & 10 \\
\hline & $1 .(2.4) .3 .5$ & - & 10 & - & 5 & \\
\hline Spines of the pharynx & Present with uniform distribution & 100 & 100 & 100 & 100 & 100 \\
\hline Striae of the pharynx & Present & 100 & 100 & 100 & 100 & 100 \\
\hline Labial fork & Present & 100 & 100 & 100 & 100 & 100 \\
\hline Proximal prolongation of ascoids & Rudimental & 100 & 100 & 100 & 100 & 100 \\
\hline Terminal part of proximal of ascoids & Rounded & 100 & 100 & 100 & 100 & 100 \\
\hline Distal prolongation of ascoids & $\begin{array}{l}\text { Reaching or not surpassing the } \\
\text { end of the flagellomere }\end{array}$ & 100 & 100 & 100 & 100 & 100 \\
\hline Colour pronotum & Well pigmented & 100 & 100 & 100 & 100 & 100 \\
\hline Colour pre-scutum & Well pigmented & 100 & 100 & 100 & 100 & 100 \\
\hline Colour scutum & Well pigmented & 100 & 100 & 100 & 100 & 100 \\
\hline Colour post-scutellum & Well pigmented & 100 & 100 & 100 & 100 & 100 \\
\hline Colour katepisternum & Lightly pigmented & 100 & 100 & 100 & 100 & 100 \\
\hline Colour anepimeron & Lightly pigmented & 100 & 100 & 100 & 100 & 100 \\
\hline Colour katepimeron & Lightly pigmented & 100 & 100 & 100 & 100 & 100 \\
\hline Colour coxa & Lightly pigmented & 100 & 100 & 100 & 100 & 100 \\
\hline \multirow[t]{3}{*}{ Pale spots on abdominal tergites } & One pale spot & 95 & - & 55 & 10 & 100 \\
\hline & Intermediate form & - & 50 & 5 & 65 & \\
\hline & Two pale spots & 5 & 50 & 40 & 25 & \\
\hline Setae tuffs on coxite & Basal & 100 & 100 & 100 & 100 & 100 \\
\hline Differentiated setae of coxite & Undifferentiated setae & 100 & 100 & 100 & 100 & 100 \\
\hline Number of setae of the coxite & Four & 100 & 100 & 100 & 100 & 100 \\
\hline Differentiated setae of paramere & Dorsal curved setae & 100 & 100 & 100 & 100 & 100 \\
\hline Shape of the style & Simple & 100 & 100 & 100 & 100 & 100 \\
\hline Subterminal setae on style & Present & 100 & 100 & 100 & 100 & 100 \\
\hline Number of spines style & Four & 100 & 100 & 100 & 100 & 100 \\
\hline Distribuition of insertion style spines & $1 / 1 / 1 / 1$ & 100 & 100 & 100 & 100 & 100 \\
\hline
\end{tabular}


TABLE III

Percentage of variations found in morphological characters in females Lutzomyia longipalpis from Salvaterra (Marajó Island, PA), São José do Ribamar (São Luís Island, MA), Canindé (CE), Natal (RN) and Lagoa Santa (Gruta da Lapinha, MG), Brazil

\begin{tabular}{|c|c|c|c|c|c|c|}
\hline \multirow[t]{2}{*}{ Character } & \multirow[t]{2}{*}{ Variation } & \multicolumn{5}{|c|}{$\%$} \\
\hline & & PA & MA & $\mathrm{CE}$ & RN & MG \\
\hline \multirow[t]{3}{*}{ Palpal formula } & 1.2.4.3.5 & 63 & 26 & 90 & 39 & 37 \\
\hline & 1.4.2.3.5 & 11 & 42 & - & 28 & 37 \\
\hline & 1.(2.4).3.5 & 26 & 32 & 10 & 33 & 26 \\
\hline \multirow[t]{2}{*}{ Number of horizontal teeth of cibarium } & 8 & 90 & 89 & 55 & 94 & 89 \\
\hline & 10 & 10 & 11 & 45 & 6 & 11 \\
\hline \multirow[t]{8}{*}{ Number of vertical teeth of cibarium } & 10 & - & - & - & 14 & \\
\hline & 11 & - & - & - & 21 & 17 \\
\hline & 12 & 52 & 68 & 44 & - & 33 \\
\hline & 13 & 12 & 16 & 6 & 30 & 50 \\
\hline & 14 & 12 & 16 & 31 & 7 & - \\
\hline & 15 & 12 & - & 6 & 14 & - \\
\hline & 16 & 12 & - & 13 & - & \\
\hline & 17 & - & - & - & - & \\
\hline Spines of the pharynx & Present with uniform distribution & 100 & 100 & 100 & 100 & 100 \\
\hline Striae of the pharynx & Present & 100 & 100 & 100 & 100 & 100 \\
\hline Labial fork & Present & 100 & 100 & 100 & 100 & 100 \\
\hline \multirow[t]{6}{*}{ Teeth in the lacinea } & 4 & - & 7 & - & 5 & \\
\hline & 5 & 32 & 32 & - & 21 & 7 \\
\hline & 6 & 47 & 20 & 24 & 26 & 33 \\
\hline & 7 & 16 & 7 & 29 & 47 & 47 \\
\hline & 8 & 5 & 28 & 47 & - & 13 \\
\hline & 9 & - & 7 & - & - & \\
\hline \multirow[t]{9}{*}{ Teeth internal in the lacinea } & 15 & - & - & - & - & - \\
\hline & 17 & - & - & 8 & - & 17 \\
\hline & 18 & - & 25 & 25 & 11 & \\
\hline & 19 & - & - & 17 & 39 & 17 \\
\hline & 20 & 15.5 & 50 & 17 & 11 & \\
\hline & 21 & 23 & 25 & 17 & 22 & 17 \\
\hline & 22 & 15.5 & - & 17 & - & \\
\hline & 23 & 23 & - & - & 11 & 49 \\
\hline & 24 & 23 & - & - & - & - \\
\hline Number of apicolateral teeth & 13 & - & - & 6 & - & \\
\hline \multirow{6}{*}{ of the hypopharynx } & 14 & 8 & 62 & 19 & - & 33 \\
\hline & 15 & 42 & 25 & 19 & 63 & 17 \\
\hline & 16 & 25 & 13 & 31 & 31 & 42 \\
\hline & 17 & 8 & - & 25 & 6 & 8 \\
\hline & 18 & 8 & - & - & - & \\
\hline & 20 & 8 & - & - & - & \\
\hline Proximal prolongation of ascoids & Rudimental & 100 & 100 & 100 & 100 & 100 \\
\hline Terminal part of proximal ascoids & Rounded & 100 & 100 & 100 & 100 & 100 \\
\hline \multirow[t]{3}{*}{ Distal prolongation of ascoids } & Reaching or not surpassing the & & & & & \\
\hline & end of the flagellomere & 22 & 31 & 50 & 10 & 100 \\
\hline & $\begin{array}{l}\text { Reaching and surpassing the end } \\
\text { of the flagellomere }\end{array}$ & 78 & 69 & 50 & 90 & \\
\hline Colour pronotum & Well pigmented & 100 & 100 & 100 & 100 & 100 \\
\hline Colour pre-scutum & Well pigmented & 100 & 100 & 100 & 100 & 100 \\
\hline Colour scutum & Well pigmented & 100 & 100 & 100 & 100 & 100 \\
\hline Colour post-scutellum & Well pigmented & 100 & 100 & 100 & 100 & 100 \\
\hline Colour katepisternum & Lightly pigmented & 100 & 100 & 100 & 100 & 100 \\
\hline Colour anepimeron & Lightly pigmented & 100 & 100 & 100 & 100 & 100 \\
\hline Colour katepimeron & Lightly pigmented & 100 & 100 & 100 & 100 & 100 \\
\hline Colour coxa & Lightly pigmented & 100 & 100 & 100 & 100 & 100 \\
\hline Aspect spermathecae bodies & Formed by annulations & 100 & 100 & 100 & 100 & 100 \\
\hline \multicolumn{7}{|l|}{ Aspect of annulations of the } \\
\hline spermathecae bodies & No imbricated & 100 & 100 & 100 & 100 & 100 \\
\hline Aspects individual ducts & Smooth non-sclerotized & 100 & 100 & 100 & 100 & 100 \\
\hline Width of individual ducts & Uniform & 100 & 100 & 100 & 100 & 100 \\
\hline Axis of spermathecae head & Not curved & 100 & 100 & 100 & 100 & 100 \\
\hline
\end{tabular}


3rd tergite is smaller than the other in the 4th tergite) and two-spotted form, while in the RN population the intermediate form occurred more frequently.

Variations occurred in the females in some quantitative morphological characters: the number of horizontal and vertical teeth on the cibarium, the number of external and internal teeth on the maxilla, and the number of teeth on the hypopharynx, which normally display considerable variation within the same species. Variations were also observed in qualitative characters: the formula of the palpus and the relationship of the distal prolongation of the ascoids. As in males, the most frequent palpus formula in females was 1.2.4.3.5. With regard to the distal prolongation of the ascoids, the only population in which we observed no variation was the one of MG, in which this character reached the middle of the flagellomere and did not extend beyond its extremity. In the other populations, except for the one of $\mathrm{CE}$, the predominant feature was the distal prolongation reaching the middle of the flagellomere and extending beyond its extremity.

Morphometrics. Homogeneity in relation to geographical origin - In order to verify the homogeneity of the population samples, we applied the tests as shown in Tables IV and V. The results suggest that there is not a total homogeneity among the samples. Therefore, we applied the SNK test in order to identify possible heterogeneous populations. In order to better evaluate the correlation between populations, we considered characters whose means displayed statistically significant differences, and the results are shown graphically.

In the illustration of the SNK test results, each diagram represents the character's mean for each population. Union, disjunction, and intersection were the operations performed among the sets. The elements of a set (sub-sets or populations) make up the universe of the L. longipalpis population analyzed for each character. When the sub-sets are analyzed separately, the CE and MG populations were the ones that generally reached extreme values, establishing a disjunction between the two. The disjunction became more evident when the union of the PA, MA, CE and RN populations was performed to form the North/Northeast set, thereby revealing, on the basis of 13 male and 19 female characters, the separation between them now considered two sets (North/Northeast and MG - Figs $2,3)$. The union of the sub-sets occurred when the differences between the means obtained for the populations in the morphometric studies were not significant. In the opposite case, disjunction occurred. The intersections indicated that at the 5\% level, the test was not capable of separating popu- lations based on sharing of values by two or more populations.

Morphometrics. Homogeneity in relation to number of spots - In order to verify the populations' homogeneity with regard to variations in the spot patterns, we applied statistical tests as shown in Tables VI, VII, and VIII. Analyses of the population samples from RN, CE and MA proved inconsistent with the populations' heterogeneity from the taxonomic point of view. In the RN population (Table VIII), only the lengths of the piston and genital pump displayed significant values at the 5\% level. Likewise, in the CE population (Table VII), the only significant value was for the length of the $\mathrm{F}_{14}$ antennal segment. No character in the MA population (Table VI) was considered significant. Although the Salvaterra population displayed variation in the spot pattern, it was not possible to perform the homogeneity test for variance, because one of the patterns (two pairs of spots) was only found in one individual.

Isoenzymatic studies - Gene frequencies for the ten allozyme loci in the four populations is given in Table IX. Six loci were polymorphic (i.e., the frequency of the more common allele was less than $0.95)$. Heterozygosity values ranged from 0.149 (RN) to 0.215 (PA). The mean number of individuals analyzed per locus and the mean number of alleles per locus are shown in Table X. All of the populations were in Hardy-Weinberg equilibrium, except for MG, which showed a heterozygote deficiency at two loci (ME: $\mathrm{F}_{\mathrm{IS}}=0.402$, $\chi^{2}=21.01, \mathrm{p}<0.001 ;$ GPI: $\mathrm{F}_{\mathrm{IS}}=0.474, \chi^{2}=14.83$, $\mathrm{p}<0.005)$. It is also worth noting that three other loci (MPI, PGM and IDH), showed high positive $\mathrm{F}_{\mathrm{IS}}$ values for MG population, even thought these were not significant. None of the loci was diagnostic (Ayala 1983) for any particular population, leading to low overall D levels (Table XII). The genetic distances were used to build a UPGMA dendrogram of the four populations (Fig. 4). However, despite the low D levels, we observed that the three northern populations (PA, MA and RN) were very similar, differing from the southernmost MG population. Furthermore, we observed that the northern population shared some unique alleles that were not present in the MG population, and vice versa. To facilitate the analysis and to test the legitimacy of the differences between the northern populations and the southern one, the frequencies of the former were grouped and analyzed as one single population. Differences between these two groups in terms of allele frequencies were confirmed by a contingency table (Table XIII). Differences in allele frequencies were also detected by the mean fixation index value (Table XI) revealing a moderate level of genetic structuring 
TABLE IV

Homogeneity of quantitative characteres in males of Lutzomyia longipalpis populations from Salvaterra (Marajó Island, PA), São José do Ribamar (São Luís Island, MA), Canindé (CE), Natal (RN) and Lagoa Santa (Gruta da Lapinha, MG), Brazil

\begin{tabular}{|c|c|c|c|c|c|c|}
\hline Character & $\begin{array}{l}\text { Number of } \\
\text { specimens }\end{array}$ & $\begin{array}{l}\text { Minimum } \\
\text { maximum } \\
(\mu \mathrm{m})\end{array}$ & $\begin{array}{c}\text { Mean } \pm \text { standard } \\
\text { deviation } \\
(\mu \mathrm{m})\end{array}$ & $\begin{array}{c}\text { ANOVA } \\
\mathrm{p}\end{array}$ & $\begin{array}{c}\text { Levene test } \\
\mathrm{p}\end{array}$ & $\begin{array}{c}\text { Kruskall-Wallis } \\
\text { p }\end{array}$ \\
\hline Length of frontal head & 100 & $290-380$ & $329.9 \pm 16.3$ & 0.021 & 0.185 & - \\
\hline Length of head & 100 & $430-550$ & $488.7 \pm 21,2$ & 0.034 & 0.091 & - \\
\hline Length of labrum-epipharynx & 100 & $240-320$ & $276.0 \pm 18.8$ & 0.0 & 0.004 & - \\
\hline Length of 1st palpal segment & 100 & $40-55$ & $48.1 \pm 3.2$ & 0.006 & 0.956 & - \\
\hline Length of 2nd palpal segment & 100 & $130-200$ & $152.0 \pm 12.6$ & 0.006 & 0.0 & - \\
\hline Length of 3rd palpal segment & 100 & $165-250$ & $193.5 \pm 14.6$ & 0.0003 & 0.0 & - \\
\hline Length of 4th palpal segment & 100 & $145-220$ & $168.6 \pm 13.0$ & 0.062 & 0.0 & 0.059 \\
\hline Length of 5th palpal segment & 98 & $305-550$ & $462.6 \pm 45.0$ & 0.039 & 0.022 & - \\
\hline Length of clipeo & 100 & $140-190$ & $158.4 \pm 8.8$ & 0.151 & 0.319 & - \\
\hline Minimal distance between eyes & 97 & $80-140$ & $117.9 \pm 14.1$ & 0.004 & 0.008 & - \\
\hline Length of $F_{1}$ antennal segment & 100 & $260-390$ & $317.0 \pm 27.0$ & 0.0 & 0.0 & - \\
\hline Length of $F_{2}$ antennal segment & 99 & $110-170$ & $140.2 \pm 12.2$ & 0.0 & 0.0 & - \\
\hline Length of $\mathrm{F}_{13}$ antennal segment & 96 & $50-65$ & $56.7 \pm 3.6$ & 0.0 & 0.057 & - \\
\hline Length of $\mathrm{F}_{14}$ antennal segment & 96 & $55-75$ & $67.3 \pm 3.6$ & 0.0003 & 0.433 & - \\
\hline Width of wing & 100 & $525-775$ & $681.7 \pm 58.6$ & 0.0 & 0.0 & - \\
\hline Length of $R_{5}$ veins of wing & 100 & $1300-1775$ & $1515.5 \pm 112.1$ & 0.0 & 0.0 & - \\
\hline Length of alfa veins of wing & 100 & $300-500$ & $393.3 \pm 43.6$ & 0.0 & 0.339 & - \\
\hline Length of beta veins of wing & 100 & $225-425$ & $318.8 \pm 35.7$ & 0.0 & 0.105 & - \\
\hline Length of gama veins of wing & 100 & $325-550$ & $442.0 \pm 48.7$ & 0.0 & 0.033 & - \\
\hline Length of delta veins of wing & 100 & $0-175$ & $76.5 \pm 31.9$ & 0.001 & 0.575 & - \\
\hline Length of fore femur & 100 & $750-1025$ & $861.2 \pm 53.4$ & 0.0 & 0.002 & - \\
\hline Length of mid femur & 100 & $750-1000$ & $875.5 \pm 48.4$ & 0.0001 & 0.081 & - \\
\hline Length of hind femur & 98 & $875-1125$ & $998.7 \pm 60.0$ & 0.0005 & 0.006 & - \\
\hline Length of fore tibia & 100 & $825-1100$ & $954.7 \pm 62.3$ & 0.0 & 0.001 & - \\
\hline Length of mid tibia & 100 & $1050-1425$ & $1220.5 \pm 89.9$ & 0.0 & 0.0 & - \\
\hline Length of hind tibia & 98 & $1325-1825$ & $1560.9 \pm 108.9$ & 0.0 & 0.008 & - \\
\hline Length of fore tarsomere & 100 & $450-600$ & $520.5 \pm 34.5$ & 0.0 & 0.033 & - \\
\hline Length of mid tarsomere & 100 & $525-750$ & $643.0 \pm 44.1$ & 0.0 & 0.795 & - \\
\hline Length of hind tarsomere & 96 & $675-950$ & $787.7 \pm 53.5$ & 0.0 & 0.799 & - \\
\hline Length of coxite & 100 & $360-450$ & $411.0 \pm 16.0$ & 0.0022 & 0.0 & - \\
\hline Width of coxite & 100 & $100-150$ & $136.5 \pm 11.0$ & 0.078 & 0.12 & - \\
\hline Length of lateral lobe & 100 & $380-490$ & $423.8 \pm 23.6$ & 0.0 & 0.0 & - \\
\hline Length of genital pump & 100 & $130-190$ & $154.1 \pm 9.7$ & 0.0101 & 0.222 & - \\
\hline Length of piston & 100 & $100-170$ & $126.8 \pm 11.0$ & 0.0152 & 0.048 & - \\
\hline Length of genital filament & 99 & $390-570$ & $469.5 \pm 39.6$ & 0.0 & 0.001 & - \\
\hline Length of style & 100 & $190-230$ & $214.5 \pm 9.4$ & 0.0 & 0.0 & - \\
\hline $\begin{array}{l}\text { Distance between the setae } \\
\text { and apical part of paramere }\end{array}$ & 100 & $90-140$ & $121.6 \pm 8.4$ & 0.0 & 0.0 & - \\
\hline
\end{tabular}

Significant values in bold $(\mathrm{p}<0.05)$

among the populations and leading to the estimated number of 3.6 migrants per generation.

\section{DISCUSSION}

L. longipalpis has been found in both the periphery of large cities and in rural areas of Brazil. This sand fly species occurs under different geographical conditions and is distributed throughout various regions of Brazil. Geographical barriers could be preventing the migration of specimens from one region to another that would account for observed morphological and biochemical variation.

The lack of a standard to describe the species, the dissociation between the sexes, the large amount of synonymy and lack of knowledge exchange between taxonomists are factors impeding the proper identification of sand fly species.

When first Lutz and Neiva described sandflies in Brazil in 1912, they reported their difficulties in classifying the species, due to the limited number 
TABLE V

Homogeneity of quantitative characteres in females of Lutzomyia longipalpi Salvaterra (Marajó Island, PA), São José do Ribamar (São Luís Island, MA), Canindé (CE), Natal (RN) and Lagoa Santa (Gruta da Lapinha, MG),

Brazil

\begin{tabular}{|c|c|c|c|c|c|c|}
\hline Character & $\begin{array}{l}\text { Number of } \\
\text { specimens }\end{array}$ & $\begin{array}{l}\text { Minimum } \\
\text { maximum } \\
\qquad(\mu \mathrm{m})\end{array}$ & $\begin{array}{c}\text { Mean } \pm \text { standard } \\
\text { deviation } \\
(\mu \mathrm{m})\end{array}$ & $\begin{array}{c}\text { ANOVA } \\
\mathrm{p}\end{array}$ & $\begin{array}{c}\text { Levene test } \\
\mathrm{p}\end{array}$ & $\begin{array}{c}\text { Kruskall-Wallis } \\
\mathrm{p}\end{array}$ \\
\hline Length of frontal head & 100 & $280-370$ & $328.5 \pm 18.7$ & 0.0247 & 0.043 & - \\
\hline Length of head & 100 & $420-550$ & $492.5 \pm 25.4$ & 0.0084 & 0.005 & - \\
\hline Length of labrum-epipharynx & 100 & $290-390$ & $339.0 \pm 19.7$ & 0.0 & 0.489 & - \\
\hline Length of 1st palpal segment & 100 & $45-60$ & $51.1 \pm 4.1$ & 0.0 & 0.024 & - \\
\hline Length of 2 nd palpal segment & 100 & $145-195$ & $163.9 \pm 11.4$ & 0.0 & 0.404 & - \\
\hline Length of 3rd palpal segment & 99 & $170-230$ & $197.6 \pm 13.5$ & 0.0 & 0.005 & - \\
\hline Length of 4 th palpal segment & 99 & $145-195$ & $166.8 \pm 10.6$ & 0.0243 & 0.0 & - \\
\hline Length of 5th palpal segment & 94 & $285-579$ & $452.6 \pm 47.6$ & 0.0 & 0.486 & - \\
\hline Length of clipeo & 100 & $120-190$ & $163.0 \pm 12.3$ & 0.0 & 0.021 & - \\
\hline Minimal distance between eyes & 96 & $80-150$ & $129.2 \pm 11.4$ & 0.0397 & 0.556 & - \\
\hline Length of $F_{1}$ antennal segment & 100 & $200-300$ & $251.7 \pm 23.0$ & 0.0 & 0.0 & - \\
\hline Length of $\mathrm{F}_{2}$ antennal segment & 100 & $100-140$ & $114.5 \pm 10.7$ & 0.0 & 0.001 & - \\
\hline Length of $\mathrm{F}_{13}$ antennal segment & 79 & $50-65$ & $55.6 \pm 3.3$ & $\mathbf{0 . 0}$ & 0.01 & - \\
\hline Length of $\mathrm{F}_{14}$ antennal segment & 100 & $60-75$ & $66.7 \pm 3.3$ & 0.0358 & 0.505 & - \\
\hline Width of wing & 100 & $600-875$ & $725.7 \pm 60.2$ & 0.0 & 0.0 & - \\
\hline Length of $R_{5}$ veins of wing & 100 & $1325-1875$ & $1584.3 \pm 134.1$ & 0.0 & 0.001 & - \\
\hline Length of alfa veins of wing & 100 & $325-575$ & $423.7 \pm 49.0$ & $\mathbf{0 . 0}$ & 0.001 & - \\
\hline Length of beta veins of wing & 100 & $250-425$ & $331.2 \pm 38.2$ & 0.0001 & 0.179 & - \\
\hline Length of gama veins of wing & 100 & $325-625$ & $459.0 \pm 68.9$ & 0.0 & 0.083 & - \\
\hline Length of delta veins of wing & 100 & $0-75$ & $87.7 \pm 37.6$ & 0.0 & 0.158 & - \\
\hline Length of fore femur & 91 & $700-975$ & $841.2 \pm 55.9$ & 0.0 & 0.097 & - \\
\hline Length of mid femur & 92 & $750-1000$ & $863.3 \pm 55.9$ & $\mathbf{0 . 0}$ & 0.394 & - \\
\hline Length of hind femur & 90 & $825-1150$ & $996.1 \pm 71.2$ & $\mathbf{0 . 0}$ & 0.024 & - \\
\hline Length of fore tibia & 91 & $700-1000$ & $838.7 \pm 71.7$ & 0.0 & 0.239 & - \\
\hline Length of mid tibia & 91 & $900-1300$ & $1081.3 \pm 86.7$ & 0.0 & 0.029 & - \\
\hline Length of hind tibia & 90 & $1150-1725$ & $1438.8 \pm 122.6$ & 0.0 & 0.086 & - \\
\hline Length of fore tarsomere & 90 & $400-675$ & $465.0 \pm 43.0$ & 0.0 & 0.122 & - \\
\hline Length of mid tarsomere & 91 & $500-700$ & $564.5 \pm 45.6$ & 0.0 & 0.529 & - \\
\hline Length of hind tarsomere & 90 & $625-875$ & $738.0 \pm 56.8$ & $\mathbf{0 . 0}$ & 0.88 & - \\
\hline Length of spermatheca body & 95 & $10-15$ & $13.4 \pm 1.5$ & 0.0018 & 0.694 & - \\
\hline Width of spermatheca body & 95 & $25-40$ & $30.1 \pm 3.2$ & 0.0 & 0.0 & - \\
\hline \multicolumn{7}{|l|}{ Length of individual duct } \\
\hline spermateca & 66 & $150-230$ & $196.1 \pm 19.3$ & 0.0 & 0.187 & - \\
\hline Length of cercus & 99 & $140-170$ & $157.1 \pm 7.6$ & $\mathbf{0 . 0}$ & 0.225 & - \\
\hline
\end{tabular}

Significant values in bold $(\mathrm{p}<0.05)$

of specimens collected for comparative studies. The authors described the males and females of L. longipalpis, providing only an overall description of the body and the alar and palpal indexes. In 1924, Nuñez-Tovar in Venezuela described the male of Phlebotomus otamae, and in 1934 Galliard described the female of $P$. almazani, with the two being placed in synonymy (Dyar \& Nuñez-Tovar 1926/27, Fairchild \& Hertig 1958).

L. longipalpis has a wide distribution in the Americas and is adapted to different ecological systems, and Mangabeira (1969) thus discussed the ability of this sand fly species to survive in such diverse habitats as the States of PA and CE, Brazil. Besides its geographical distribution, the author suggested $L$. longipalpis as a complex of cryptic species and considered different pale-spotted patterns on the abdominal tergites. Dujardin et al. (1997), studying the morphometrics of wing veins in L. longipalpis males from Nicaragua, Colombia, Bolivia and Brazil, suggested that Bolivian populations with one and two pairs of pale spots 


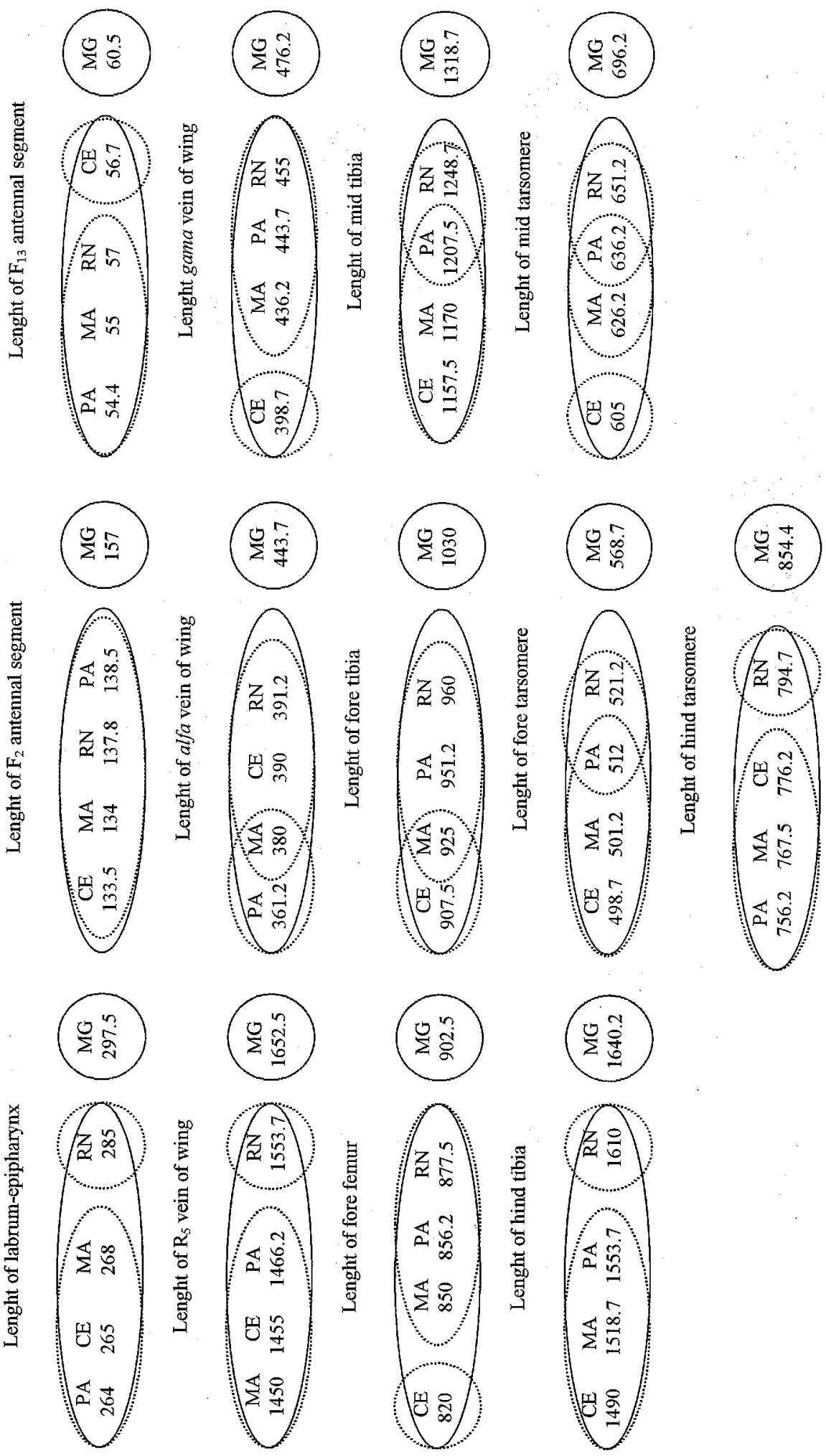

Fig. 2: Euler-Venn diagram according to Student-Newman-Keuls comparing male populations of Lutzomyia longipalpis from Gruta da Lapinha (MG) and North/Northeast populations (PA, MA, CE, RN). Continuous line: analysis of the populations as two groups - North/Northeast (PA, MA, CE, RN) and Gruta da Lapinha (MG). Interrupted line: analysis of individual populations, PA: Pará; MA: Maranhão; CE: Ceará; RN: Rio Grande do Norte; MG: Minas Gerais. 
Studies on Populations of L. longipalpis - Alfredo CR de Azevedo et al.
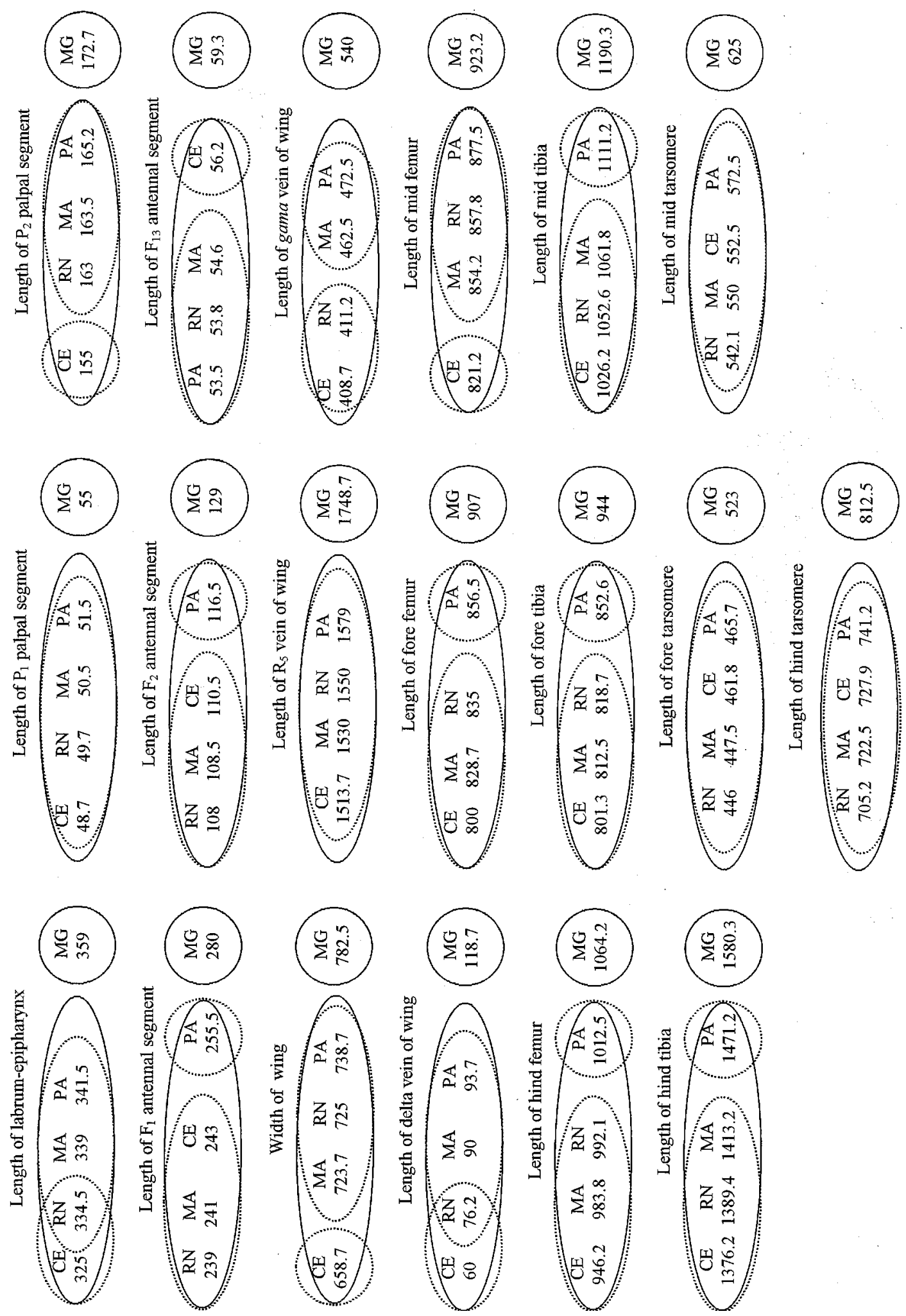

Fig. 3: Euler-Venn diagram according to Student-Newman-Keuls comparing female populations of Lutzomyia longipalpis from Gruta da Lapinha (MG) and North/Northeast populations (PA, MA, CE, RN). Continuous line: analysis of populations as two groups - North/Northeast (PA, MA, CE, RN) and Gruta da Lapinha (MG). Interrupted line: analysis of individual populations, PA: Pará; MA: Maranhão; CE: Ceará; RN: Rio Grande do Norte; MG: Minas Gerais. 
TABLE VI

Homogeneity of quantitative characters related to pale spots (two spots and intermediate form) in Lutzomyia longipalpis males from São José do Ribamar (MA), Brazil

\begin{tabular}{|c|c|c|c|c|c|c|c|}
\hline \multirow[b]{2}{*}{ Characters } & \multicolumn{2}{|c|}{ Intermediate form } & \multicolumn{2}{|c|}{ Two spots } & \multirow[b]{2}{*}{$\begin{array}{c}\text { ANOVA } \\
\mathrm{p}\end{array}$} & \multirow[b]{2}{*}{$\begin{array}{l}\text { Levene test } \\
p\end{array}$} & \multirow[b]{2}{*}{$\begin{array}{c}\text { Kruskall-Wallis } \\
\mathrm{p}\end{array}$} \\
\hline & $\begin{array}{l}\text { Number of } \\
\text { specimens }\end{array}$ & $\begin{array}{c}\text { Mean } \pm \text { standard } \\
\text { deviation }(\mu \mathrm{m})\end{array}$ & $\begin{array}{l}\text { Number of } \\
\text { specimens }\end{array}$ & $\begin{array}{l}\text { Mean } \pm \text { standard } \\
\text { deviation }(\mu \mathrm{m})\end{array}$ & & & \\
\hline Length of frontal head & 10 & $327.0 \pm 8.2$ & 10 & $327.0 \pm 11.6$ & 1.000 & 0.416 & - \\
\hline Length of head & 10 & $484.0 \pm 11.7$ & 10 & $483.0 \pm 13.4$ & 0.861 & 0.948 & - \\
\hline Length of labrum-epipharynx & 10 & $267.0 \pm 6.7$ & 10 & $269.0 \pm 8.8$ & 0.574 & 0.366 & - \\
\hline Length of 1st palpal segment & 10 & $47.5 \pm 2.6$ & 10 & $48.0 \pm 2.6$ & 0.673 & 0.548 & - \\
\hline Length of 2nd palpal segment & 10 & $148.0 \pm 4.8$ & 10 & $150.5 \pm 6.0$ & 0.318 & 0.575 & - \\
\hline Length of 3rd palpal segment & 10 & $189.0 \pm 5.2$ & 10 & $188.0 \pm 6.7$ & 0.714 & 0.41 & - \\
\hline Length of 4th palpal segment & 10 & $161.5 \pm 6.3$ & 10 & $164.5 \pm 6.9$ & 0.320 & 0.787 & - \\
\hline Length of 5th palpal segment & 10 & $445.0 \pm 26.0$ & 10 & $458.0 \pm 38.7$ & 0.389 & 0.219 & - \\
\hline Length of clipeo & 10 & $155.0 \pm 8.5$ & 10 & $156.0 \pm 7.0$ & 0.777 & 0.548 & - \\
\hline Minimal distance between eyes & 9 & $124.4 \pm 12.4$ & 10 & $122.0 \pm 4.2$ & 0.563 & 0.022 & 0.462 \\
\hline Length of $\mathrm{F}_{1}$ antennal segment & 10 & $310.0 \pm 9.4$ & 10 & $305.0 \pm 8.5$ & 0.229 & 0.602 & - \\
\hline Length of $F_{2}$ antennal segment & 10 & $135.0 \pm 5.3$ & 10 & $133.0 \pm 4.8$ & 0.388 & 0.207 & - \\
\hline Length of $F_{13}$ antennal segment & 10 & $54.5 \pm 2.8$ & 10 & $55.5 \pm 1.6$ & 0.343 & 0.263 & - \\
\hline Length of $\mathrm{F}_{14}$ antennal segment & 10 & $66.0 \pm 3.2$ & 10 & $65.5 \pm 2.8$ & 0.714 & 0.512 & - \\
\hline Width of wing & 10 & $675.0 \pm 40.8$ & 10 & $667.5 \pm 26.5$ & 0.632 & 0.278 & - \\
\hline Length of $R_{5}$ veins of wing & 10 & $1457.5 \pm 65.7$ & 10 & $1442.5 \pm 40.9$ & 0.547 & 0.166 & - \\
\hline Length of alfa veins of wing & 10 & $377.5 \pm 27.5$ & 10 & $382.5 \pm 20.6$ & 0.651 & 0.288 & - \\
\hline Length of beta veins of wing & 10 & $312.5 \pm 17.7$ & 10 & $315.0 \pm 21.1$ & 0.777 & 0.648 & - \\
\hline Length of gama veins of wing & 10 & $437.5 \pm 46.0$ & 10 & $435.0 \pm 26.9$ & 0.884 & 0.064 & - \\
\hline Length of delta veins of wing & 10 & $72.5 \pm 32.2$ & 10 & $70.0 \pm 15.8$ & 0.828 & 0.125 & - \\
\hline Length of fore femur & 10 & $855.0 \pm 32.9$ & 10 & $845.0 \pm 28.4$ & 0.476 & 0.256 & - \\
\hline Length of mid femur & 10 & $880.0 \pm 32.9$ & 10 & $867.5 \pm 29.0$ & 0.379 & 0.333 & - \\
\hline Length of hind femur & 10 & $990.0 \pm 31.6$ & 10 & $1000.0 \pm 33.3$ & 0.500 & 0.8 & - \\
\hline Length of fore tibia & 10 & $937.5 \pm 29.5$ & 10 & $912.5 \pm 39.5$ & 0.126 & 0.331 & - \\
\hline Length of mid tibia & 10 & $1180.0 \pm 42.2$ & 10 & $1160.0 \pm 63.7$ & 0.418 & 0.21 & - \\
\hline Length of hind tibia & 10 & $1535.0 \pm 80.1$ & 10 & $1502.5 \pm 79.5$ & 0.374 & 0.602 & - \\
\hline Length of fore tarsomere & 10 & $500.0 \pm 11.8$ & 10 & $502.5 \pm 24.9$ & 0.777 & 0.224 & - \\
\hline Length of mid tarsomere & 10 & $622.5 \pm 27.5$ & 10 & $630.0 \pm 28.4$ & 0.556 & 0.865 & - \\
\hline Length of hind tarsomere & 10 & $770.0 \pm 45.3$ & 10 & $765.0 \pm 45.9$ & 0.809 & 0.928 & - \\
\hline Length of coxite & 10 & $414.0 \pm 5.2$ & 10 & $412.0 \pm 7.9$ & 0.511 & 0.246 & - \\
\hline Width of coxite & 10 & $140.0 \pm 10.5$ & 10 & $145.0 \pm 8.5$ & 0.258 & 0.037 & 0.345 \\
\hline Length of lateral lobe & 10 & $416.0 \pm 7.0$ & 10 & $414.6 \pm 6.9$ & 0.530 & 1.000 & - \\
\hline Length of genital pump & 10 & $156.0 \pm 8.4$ & 10 & $153.0 \pm 4.8$ & 0.342 & 0.107 & - \\
\hline Length of piston & 10 & $128.0 \pm 10.3$ & 10 & $126.0 \pm 7.0$ & 0.618 & 0.229 & - \\
\hline Length of genital filament & 10 & $451.0 \pm 23.8$ & 10 & $445.0 \pm 24.6$ & 0.586 & 0.874 & - \\
\hline Length of style & 10 & $210.0 \pm 0.0$ & 10 & $210.0 \pm 0.0$ & - & - & - \\
\hline Distance between the setae and apical part of paramere & 10 & $119.0 \pm 3.2$ & 10 & $120.0 \pm 0.0$ & 0.331 & 0.037 & 0.317 \\
\hline
\end{tabular}


TABLE VII

Homogeneity of quantitative characters related to pale spots (one, two spots and intermediate form) in Lutzomyia longipalpis males from Canindé (CE), Brazil

\begin{tabular}{|c|c|c|c|c|c|c|c|c|c|}
\hline \multirow[t]{2}{*}{ Characters } & \multicolumn{2}{|c|}{ One spot } & \multicolumn{2}{|c|}{ Intermediate form } & \multicolumn{2}{|c|}{ Two spots } & \multirow{2}{*}{$\begin{array}{c}\text { ANOVA } \\
\mathrm{p}\end{array}$} & \multirow{2}{*}{$\begin{array}{c}\text { Levene test } \\
\mathrm{p}\end{array}$} & \multirow{2}{*}{$\begin{array}{c}\text { Kruskall-Wallis } \\
\mathrm{p}\end{array}$} \\
\hline & $\begin{array}{l}\text { Number of } \\
\text { specimens }\end{array}$ & $\begin{array}{r}\text { Mean } \pm \text { standard } \\
\text { deviation }(\mu \mathrm{m})\end{array}$ & $\begin{array}{l}\text { Number of } \\
\text { specimens }\end{array}$ & $\begin{array}{c}\text { Mean } \pm \text { standard } \\
\text { deviation }(\mu \mathrm{m})\end{array}$ & $\begin{array}{l}\text { Number of } \\
\text { specimens }\end{array}$ & $\begin{array}{l}\text { Mean } \pm \text { standard } \\
\text { deviation }(\mu \mathrm{m})\end{array}$ & & & \\
\hline Length of frontal head & 11 & $324.5 \pm 21.5$ & 1 & 310 & 8 & $318.8 \pm 10.5$ & 0.32 & 0.053 & - \\
\hline Length of head & 11 & $480.0 \pm 28.6$ & 1 & 470 & 8 & $481.1 \pm 16.2$ & 0.939 & 0.284 & - \\
\hline Length of labrum-epipharynx & 11 & $257.3 \pm 32.2$ & 1 & 250 & 8 & $265.0 \pm 11.2$ & 0.32 & 0.053 & - \\
\hline Length of 1 st palpal segment & 11 & $46.4 \pm 4.3$ & 1 & 45 & 8 & $46.3 \pm 2.2$ & 0.911 & 0.121 & - \\
\hline Length of 2nd palpal segment & 11 & $147.3 \pm 15.1$ & 1 & 140 & 8 & $140.6 \pm 8.1$ & 0.464 & 0.332 & - \\
\hline Length of 3rd palpal segment & 11 & $183.2 \pm 10.9$ & 1 & 175 & 8 & $184.4 \pm 9.2$ & 0.876 & 0.506 & - \\
\hline Length of 4th palpal segment & 11 & $166.4 \pm 6.4$ & 1 & 160 & 8 & $165.6 \pm 5.8$ & 0.979 & 0.649 & - \\
\hline Length of 5th palpal segment & 11 & $475.9 \pm 26.4$ & 1 & 490 & 8 & $457.5 \pm 24.5$ & 0.129 & 0.653 & - \\
\hline Length of clipeo & 11 & $155.5 \pm 7.8$ & 1 & 160 & 8 & $161.3 \pm 7.8$ & 0.124 & 0.124 & - \\
\hline Minimal distance between eyes & 11 & $124.5 \pm 9.9$ & 1 & 120 & 8 & $116.3 \pm 13.2$ & 0.184 & 0.68 & - \\
\hline Length of F1 antennal segment & 11 & $301.8 \pm 20.8$ & 1 & 270 & 8 & $293.8 \pm 11.1$ & 0.113 & 0.132 & - \\
\hline Length of F2 antennal segment & 11 & $138.4 \pm 6.4$ & 1 & 130 & 8 & $130.0 \pm 8.7$ & 0.302 & 0.916 & - \\
\hline Length of F13 antennal segment & 11 & $58.2 \pm 3.2$ & 1 & 55 & 8 & $55.0 \pm 2.5$ & 0.056 & 0.105 & - \\
\hline Length of F14 antennal segment & 11 & $70.0 \pm 2.1$ & 1 & 70 & 8 & $66.3 \pm 2.2$ & 0.008 & 0.33 & - \\
\hline Width of wing & 11 & $611.4 \pm 26.9$ & 1 & 600 & 8 & $621.9 \pm 31.7$ & 0.718 & 0.78 & - \\
\hline Length of R5 veins of wing & 11 & $1459.1 \pm 51.4$ & 1 & 1400 & 8 & $1456.3 \pm 67$ & 0.977 & 0.243 & - \\
\hline Length of alfa veins of wing & 11 & $386.4 \pm 41.8$ & 1 & 425 & 8 & $390.6 \pm 27.8$ & 0.362 & 0.148 & - \\
\hline Length of beta veins of wing & 11 & $284.1 \pm 24.5$ & 1 & 300 & 8 & $303.1 \pm 34.1$ & 0.466 & 0.377 & - \\
\hline Length of gama veins of wing & 11 & $406.8 \pm 26.3$ & 1 & 375 & 8 & $390.6 \pm 37.4$ & 0.515 & 0.452 & - \\
\hline Length of delta veins of wing & 11 & $52.3 \pm 32.8$ & 1 & 25 & 8 & $59.4 \pm 17.4$ & 0.789 & 0.084 & - \\
\hline Length of fore femur & 11 & $831.8 \pm 47.8$ & 1 & 775 & 8 & $809.4 \pm 21.4$ & 0.588 & 0.02 & 0.707 \\
\hline Length of mid femur & 11 & $838.6 \pm 48.1$ & 1 & 800 & 8 & $837.5 \pm 33.1$ & 0.993 & 0.163 & - \\
\hline Length of hind femur & 11 & $961.4 \pm 52.6$ & 1 & 900 & 8 & $956.3 \pm 42.8$ & 0.862 & 0.707 & - \\
\hline Length of fore tibia & 11 & $915.9 \pm 44.3$ & 1 & 875 & 8 & $900.0 \pm 33.1$ & 0.742 & 0.377 & - \\
\hline Length of mid tibia & 11 & $1181.8 \pm 71.6$ & 1 & 1075 & 8 & $1134.4 \pm 46.7$ & 0.441 & 0.621 & - \\
\hline Length of hind tibia & 11 & $1509.1 \pm 74.1$ & 1 & 1375 & 8 & $1471.9 \pm 71.2$ & 0.632 & 0.278 & - \\
\hline Length of fore tarsomere & 11 & $506.8 \pm 28.4$ & 1 & 475 & 8 & $490.6 \pm 17.4$ & 0.538 & 0.616 & - \\
\hline Length of mid tarsomere & 11 & $613.8 \pm 35.9$ & 1 & 600 & 8 & $593.8 \pm 34.8$ & 0.325 & 0.782 & - \\
\hline Length of hind tarsomere & 11 & $788.6 \pm 32.6$ & 1 & 750 & 8 & $762.5 \pm 37.5$ & 0.431 & 0.756 & - \\
\hline Length of coxite & 11 & $400.9 \pm 17.8$ & 1 & 390 & 8 & $396.3 \pm 7$ & 0.511 & 0.096 & - \\
\hline Width of coxite & 11 & $129.1 \pm 15.6$ & 1 & 140 & 8 & $137.5 \pm 6.6$ & 0.422 & 0.006 & 0.654 \\
\hline Length of lateral lobe & 11 & $404.5 \pm 12.3$ & 1 & 390 & 8 & $400.0 \pm 10$ & 0.192 & 0.191 & - \\
\hline Length of genital pump & 11 & $148.2 \pm 10.3$ & 1 & 150 & 8 & $155.0 \pm 7.1$ & 0.326 & 0.008 & 0.443 \\
\hline Length of piston & 11 & $119.1 \pm 13.1$ & 1 & 120 & 8 & $128.8 \pm 7.8$ & 0.175 & 0.071 & - \\
\hline Length of genital filament & 11 & $428.2 \pm 27.2$ & 1 & 440 & 8 & $446.3 \pm 29.6$ & 0.474 & 0.442 & - \\
\hline Length of style & 11 & $210.0 \pm 11.3$ & 1 & 200 & 8 & $206.3 \pm 7$ & 0.688 & 0.789 & - \\
\hline $\begin{array}{l}\text { Distance between the setae and apical } \\
\text { part of paramere }\end{array}$ & 11 & $112.7 \pm 8.6$ & 1 & 120 & 8 & $115.0 \pm 7.1$ & 0.433 & 0.273 & - \\
\hline
\end{tabular}

Significant values in bold $(\mathrm{p}<0.05)$ 
TABLE VIII

Homogeneity of quantitative characters related to pale spots (one, two spots and intermediate form) in Lutzomyia longipalpis males from Natal (RN), Brazil

\begin{tabular}{|c|c|c|c|c|c|c|c|c|c|}
\hline \multirow[t]{2}{*}{ Characters } & \multicolumn{2}{|c|}{ One spot } & \multicolumn{2}{|c|}{ Intermediate form } & \multicolumn{2}{|c|}{ Two spots } & \multirow{2}{*}{$\begin{array}{c}\text { ANOVA } \\
\mathrm{p}\end{array}$} & \multirow{2}{*}{$\begin{array}{c}\text { Levene test } \\
\mathrm{p}\end{array}$} & \multirow{2}{*}{$\begin{array}{c}\text { Kruskall-Wallis } \\
\mathrm{p}\end{array}$} \\
\hline & $\begin{array}{l}\text { Number of } \\
\text { specimens }\end{array}$ & $\begin{array}{r}\text { Mean } \pm \text { standard } \\
\text { deviation }(\mu \mathrm{m})\end{array}$ & $\begin{array}{l}\text { Number of } \\
\text { specimens }\end{array}$ & $\begin{array}{c}\text { Mean } \pm \text { standard } \\
\text { deviation }(\mu \mathrm{m})\end{array}$ & $\begin{array}{l}\text { Number of } \\
\text { specimens }\end{array}$ & $\begin{array}{l}\text { Mean } \pm \text { standard } \\
\text { deviation }(\mu \mathrm{m})\end{array}$ & & & \\
\hline Length of frontal head & 2 & $335.0 \pm 7.1$ & 13 & $334.6 \pm 19.8$ & 5 & $344.0 \pm 11.4$ & 0.601 & 0.334 & - \\
\hline Length of head & 2 & $485.0 \pm 21.2$ & 13 & $492.3 \pm 24.2$ & 5 & $506.0 \pm 8.9$ & 0.397 & 0.192 & - \\
\hline Length of labrum-epipharynx & 2 & $270.0 \pm 14.1$ & 13 & $288.5 \pm 15.2$ & 5 & $284.0 \pm 5.5$ & 0.218 & 0.323 & - \\
\hline Length of 1 st palpal segment & 2 & $52.5 \pm 3.5$ & 13 & $48.8 \pm 3.0$ & 5 & $48.0 \pm 2.7$ & 0.215 & 0.993 & - \\
\hline Length of 2 nd palpal segment & 2 & $147.5 \pm 3.5$ & 13 & $155.4 \pm 8.5$ & 5 & $156.0 \pm 8.2$ & 0.437 & 0.488 & - \\
\hline Length of 3rd palpal segment & 2 & $195.0 \pm 0.0$ & 13 & $198.5 \pm 13.0$ & 5 & $198.0 \pm 10.4$ & 0.931 & 0.188 & - \\
\hline Length of 4 th palpal segment & 2 & $170.0 \pm 0.0$ & 13 & $169.6 \pm 12.8$ & 5 & $174.0 \pm 14.3$ & 0.809 & 0.293 & - \\
\hline Length of 5th palpal segment & 2 & $497.5 \pm 3.5$ & 13 & $458.5 \pm 50.8$ & 4 & $471.3 \pm 81.1$ & 0.648 & 0.107 & - \\
\hline Length of clipeo & 2 & $150.0 \pm 14.1$ & 13 & $157.7 \pm 9.3$ & 5 & $160.0 \pm 7.1$ & 0.442 & 0.3 & - \\
\hline Minimal distance between eyes & 2 & $130.0 \pm 0.0$ & 12 & $122.5 \pm 15.4$ & 5 & $116.0 \pm 20.7$ & 0.578 & 0.332 & - \\
\hline Length of $F_{1}$ antennal segment & 2 & $325.0 \pm 7.1$ & 13 & $316.9 \pm 19.3$ & 5 & $332.0 \pm 11.0$ & 0.4397 & 0.097 & - \\
\hline Length of $F_{2}$ antennal segment & 2 & $140.0 \pm 0.0$ & 12 & $138.3 \pm 9.4$ & 5 & $140.0 \pm 7.1$ & 0.697 & 0.125 & - \\
\hline Length of $F_{13}$ antennal segment & 1 & $55.0 \pm 0.0$ & 12 & $57.7 \pm 2.6$ & 5 & $56.0 \pm 2.2$ & 0.338 & 0.01 & 0.433 \\
\hline Length of $\mathrm{F}_{14}$ antennal segment & 1 & $65.0 \pm 0.0$ & 12 & $68.2 \pm 2.5$ & 5 & $69.0 \pm 2.2$ & 0.353 & 0.061 & - \\
\hline Width of wing & 2 & $700.0 \pm 70.7$ & 13 & $719.2 \pm 37.0$ & 5 & $740.0 \pm 13.7$ & 0.379 & $\mathbf{0 . 0 3 2}$ & 0.551 \\
\hline Length of $R_{5}$ veins of wing & 2 & $1462.5 \pm 123.7$ & 13 & $1559.6 \pm 57.3$ & 5 & $1575.0 \pm 46.8$ & 0.104 & 0.129 & - \\
\hline Length of alfa veins of wing & 2 & $375.0 \pm 3.5$ & 13 & $392.3 \pm 41.3$ & 5 & $395 \pm 20.9$ & 0.793 & 0.087 & - \\
\hline Length of beta veins of wing & 2 & $327.5 \pm 3.5$ & 13 & $355.8 \pm 34.1$ & 5 & $340.0 \pm 13.7$ & 0.351 & 0.011 & 0.63 \\
\hline Length of gama veins of wing & 2 & $437.5 \pm 17.7$ & 13 & $455.8 \pm 37.0$ & 5 & $460.0 \pm 45.4$ & 0.779 & 0.4 & - \\
\hline Length of delta veins of wing & 2 & $87.5 \pm 17.7$ & 13 & $96.2 \pm 32.0$ & 5 & $75.0 \pm 46.8$ & 0.535 & 0.16 & - \\
\hline Length of fore femur & 2 & $850.0 \pm 35.4$ & 13 & $880.8 \pm 37.0$ & 5 & $880.0 \pm 27.4$ & 0.514 & 0.722 & - \\
\hline Length of mid femur & 2 & $862.5 \pm 53$ & 13 & $890.4 \pm 38.9$ & 5 & $885.0 \pm 22.4$ & 0.614 & 0.228 & - \\
\hline Length of hind femur & 2 & $975.0 \pm 70.7$ & 13 & $1021.2 \pm 57.6$ & 5 & $1025.0 \pm 35.4$ & 0.513 & 0.444 & - \\
\hline Length of fore tibia & 2 & $925.0 \pm 70.7$ & 13 & $965.4 \pm 41.5$ & 5 & $960.0 \pm 37.9$ & 0.481 & 0.517 & - \\
\hline Length of mid tibia & 2 & $1187.5 \pm 53$ & 13 & $1255.8 \pm 54.2$ & 5 & $1255.0 \pm 32.6$ & 0.216 & 0.568 & - \\
\hline Length of hind tibia & 2 & $1512.5 \pm 123.7$ & 13 & $1619.2 \pm 87.3$ & 5 & $1625.0 \pm 61.2$ & 0.255 & 0.499 & - \\
\hline Length of fore tarsomere & 2 & $500.0 \pm 0.0$ & 13 & $528.8 \pm 24.7$ & 5 & $510.0 \pm 22.4$ & 0.155 & 0.157 & - \\
\hline Length of mid tarsomere & 2 & $612.5 \pm 17.7$ & 12 & $661.5 \pm 33.3$ & 5 & $640.0 \pm 28.5$ & 0.109 & 0.364 & - \\
\hline Length of hind tarsomere & 2 & $737.5 \pm 53$ & 13 & $806.3 \pm 47.8$ & 5 & $790.0 \pm 13.7$ & 0.132 & 0.057 & - \\
\hline Length of coxite & 2 & $410.0 \pm 14.1$ & 13 & $414.6 \pm 15.1$ & 5 & $410.0 \pm 10.0$ & 0.783 & 0.634 & - \\
\hline Width of coxite & 2 & $130.0 \pm 14.1$ & 13 & $137.7 \pm 11.7$ & 5 & $132.0 \pm 8.4$ & 0.783 & 0.634 & - \\
\hline Length of lateral lobe & 2 & $425.0 \pm 21.2$ & 13 & $443.8 \pm 24.3$ & 5 & $442.0 \pm 16.4$ & 0.556 & 0.744 & - \\
\hline Length of genital pump & 2 & $155.0 \pm 7.1$ & 13 & $146.2 \pm 7.7$ & 5 & $156.0 \pm 55$ & $\mathbf{0 . 0 3 7}$ & 0.685 & - \\
\hline Length of piston & 2 & $125.0 \pm 7.1$ & 13 & $118.5 \pm 8.0$ & 5 & $130.0 \pm 0.0$ & 0.017 & 0.011 & - \\
\hline Length of genital filament & 2 & $475.0 \pm 7.1$ & 13 & $503.8 \pm 21.8$ & 4 & $480.0 \pm 53.5$ & 0.25 & 0.029 & 0.228 \\
\hline Length of style & 2 & $215.0 \pm 7.1$ & 13 & $220.0 \pm 8.2$ & 5 & $214.0 \pm 5.5$ & 0.295 & 0.813 & - \\
\hline $\begin{array}{l}\text { Distance between the setae and apical } \\
\text { part of paramere }\end{array}$ & 2 & $120.0 \pm 14.1$ & 13 & $124.6 \pm 5.2$ & 5 & $128.0 \pm 4.5$ & 0.282 & 0.0 & 0.481 \\
\hline
\end{tabular}

Significant values in bold $(\mathrm{p}<0.05)$ 


\section{TABLE IX}

Gene frequencies of ten loci for Lutzomyia longipalpis specimens from four populations (Salvaterra - PA, São José do Ribamar - MA, Natal - RN, Gruta da Lapinha - MG) in Brazil

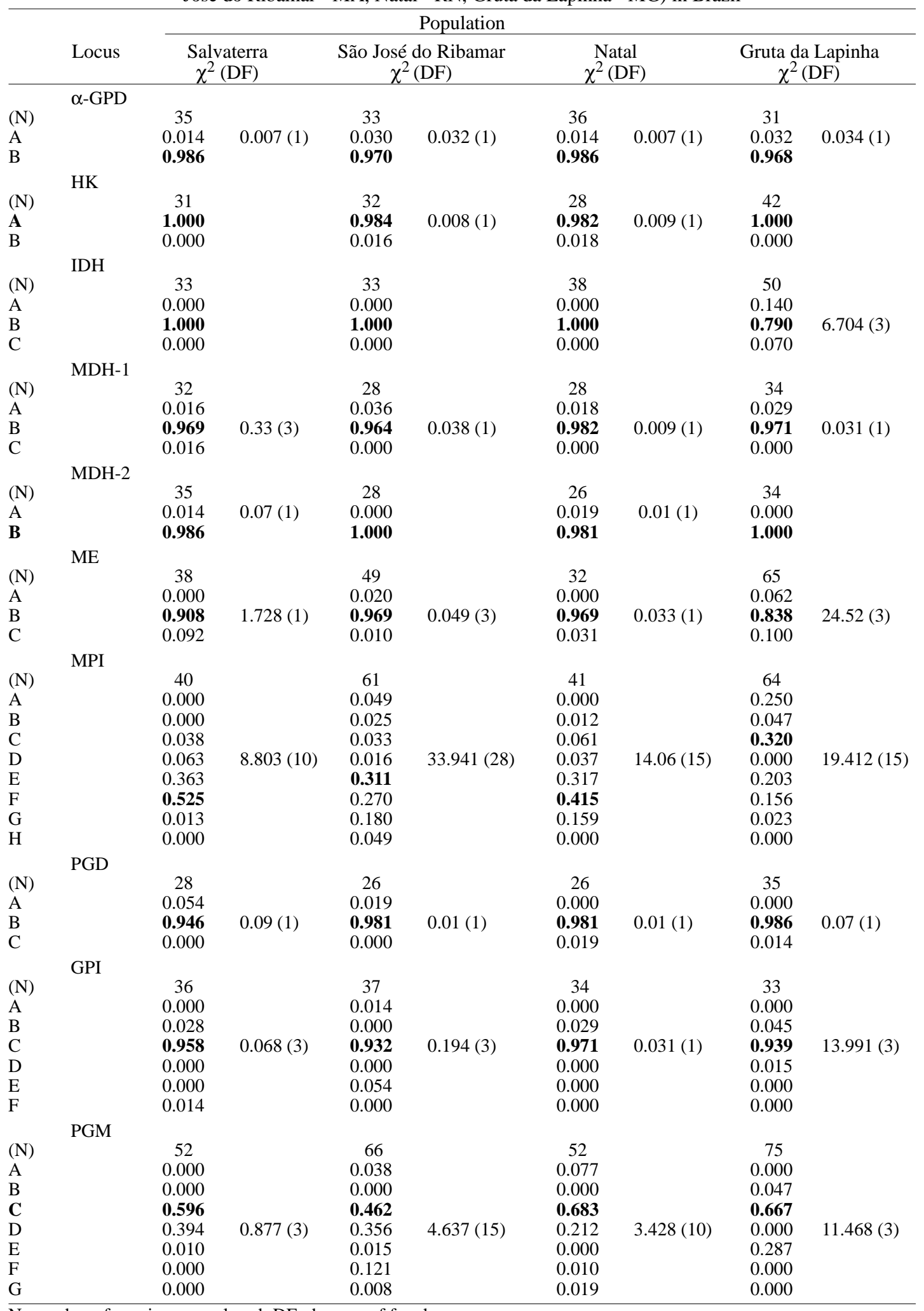

$\mathrm{N}$ : number of specimens analysed; DF: degrees of freedom 
TABLE X

Genetic variability of four populations of Lutzomyia longipalpis from Salvaterra (Marajó Island, PA), São José do Ribamar (São Luís Island, MA), Canindé (CE), Natal (RN) and Lagoa Santa (Gruta da Lapinha, MG), Brazil

\begin{tabular}{lccccc}
\hline Population & $\begin{array}{c}\text { Mean sample size } \\
\text { per locus }\end{array}$ & $\begin{array}{c}\text { Mean number of } \\
\text { alleles per locus }\end{array}$ & $\begin{array}{c}\text { Percentage of } \\
\text { polymorphic loci }\end{array}$ & \multicolumn{2}{c}{ Mean heterozigosity } \\
\cline { 5 - 6 } Salvaterra & 36.0 & 2.4 & 40 & Ho & He \\
São José do Ribamar & $(2.1)$ & $(0.4)$ & & 0.138 & 0.156 \\
& 39.3 & 3.0 & 30 & $0.057)$ & $(0.067)$ \\
Natal & $(4.5)$ & $(0.7)$ & & $(0.076)$ & 0.183 \\
& 34.1 & 2.6 & 20 & 0.144 & $0.091)$ \\
Gruta da Lapinha & $(2.6)$ & $(0.5)$ & & $(0.073)$ & $(0.077)$ \\
& 46.3 & 2.6 & 50 & 0.162 & 0.215 \\
& $(5.1)$ & $(0.5)$ & & $(0.063)$ & $(0.081)$ \\
\hline
\end{tabular}

$a$ : a locus is considered polymorphic if the frequency of the more common allele was less than 0.95 ; Ho: heterozigosity observed; He: Hardy-Weinberg expected; (standard errors).

TABLE XI

Fixation indexes for 10 isoenzymatic loci of populations of Lutzomyia longipalpis from Salvaterra (Marajó Island, PA), São José do Ribamar (São Luís Island, MA), Canindé (CE), Natal (RN) and Lagoa Santa (Gruta da Lapinha, MG), Brazil

\begin{tabular}{lll}
\hline Locus & $\mathrm{F}_{\text {IS }}$ & $\mathrm{F}_{\mathrm{ST}}$ \\
\hline$\alpha-G P D$ & -0.027 & 0.003 \\
$\mathrm{HK}$ & -0.011 & 0.006 \\
$\mathrm{IDH}$ & 0.260 & $0.089^{b}$ \\
MDH-1 & -0.027 & 0.0 \\
MDH-2 & 0.023 & $0.011^{a}$ \\
ME & 0.333 & $0.024^{a}$ \\
MPI & 0.192 & $0.076^{b}$ \\
PGD & -0.023 & $0.005^{b}$ \\
GPI & 0.251 & 0.004 \\
PGM & 0.141 & $0.087^{b}$ \\
\hline Mean & 0.181 & 0.065 \\
\hline
\end{tabular}

$a: \mathrm{p}<0.01, b: \mathrm{p}<0.001$ were different lineages. Our studies did not permit us to ascribe taxonomic importance to spot patterns as a character. The character's variation may be associated with the number of papules comprising these spots (Lane \& Ward 1984), varying from one individual to another and thus conferring different morphological profiles associated with this character. Mukhopadhyay et al. (1998), in studies on L. longipalpis populations from Natal, Brazil, with morphological variations (one and two spots and an intermediate form), observed that spot patterns and isoenzymatic frequencies fit Hardy-Weinberg expectations, and that no significant differences in isoenzymatic frequencies were associated with morphological phenotype. This demonstrates that the Natal population is panmictic.

Homogeneity tests showed that the populations analyzed (Salvaterra - PA, São José do Ribamar MA, Canindé - CE, Natal - RN and Gruta da

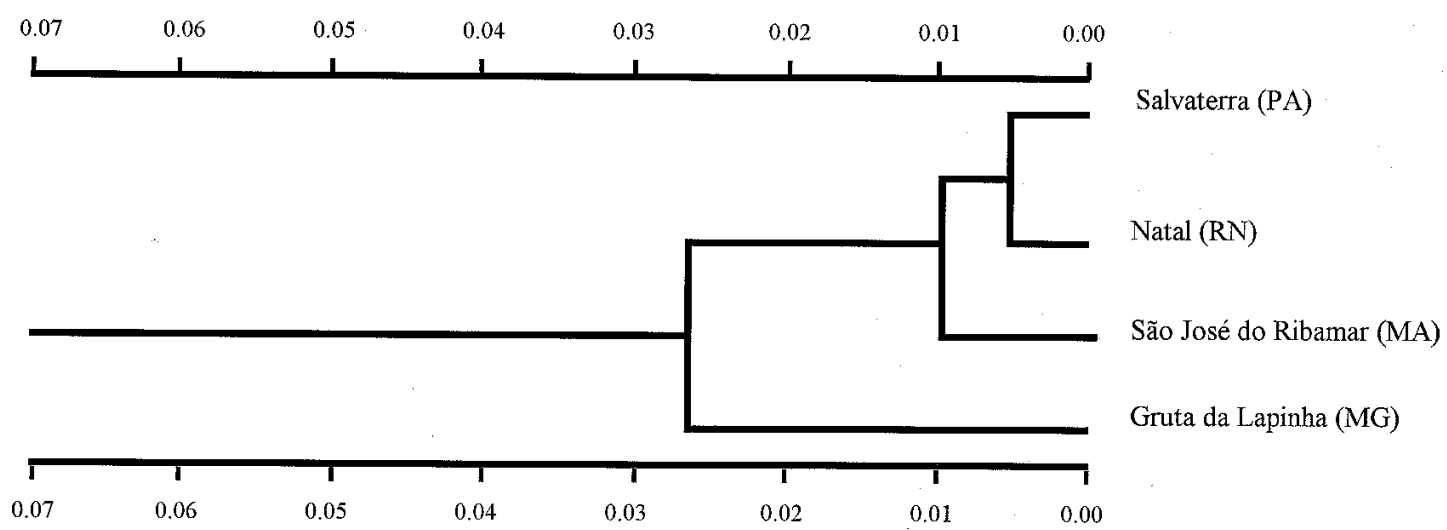

Fig. 4: UPGMA dendrogram derived from Nei's standard genetic distance among four populations of Lutzomyia longipalpis from Brazil. PA: Pará; MA: Maranhão; CE: Ceará; RN: Rio Grande do Norte; MG: Minas Gerais. 
TABLE XII

Pairwise Nei’s genetic distance among Lutzomyia longipalpis populations from Salvaterra (Marajó Island, PA), São José do Ribamar (São Luís Island, MA), Canindé (CE), Natal (RN) and Lagoa Santa (Gruta da Lapinha, MG), Brazil

\begin{tabular}{|c|c|c|c|c|}
\hline Populations & 1 & 2 & 3 & 4 \\
\hline 1 Salvaterra & $* * * * *$ & 0.004 & 0.007 & 0.037 \\
\hline 2 Natal & & $* * * * *$ & 0.005 & 0.026 \\
\hline 3 São José do Ribamar & & & $* * * * *$ & 0.032 \\
\hline 4 Gruta da Lapinha & & & & $* * * * *$ \\
\hline
\end{tabular}

TABLE XIII

Studies on the homogeneity among populations of Lutzomyia longipalpis from North/Northeast and Gruta da Lapinha, Southeast Brazil

\begin{tabular}{lcccc}
\hline Locus & $\begin{array}{c}\text { Allelos } \\
\text { number }\end{array}$ & Chi-square & DF & Probability \\
\hline$\alpha-$ GDP & 2 & 0.82 & 1 & 0.367 \\
HK & 2 & 0.93 & 1 & 0.335 \\
IDH & 3 & 46.88 & 2 & 0.0 \\
MDH1 & 3 & 0.48 & 2 & 0.788 \\
MDH2 & 2 & 1.55 & 1 & 0.213 \\
ME & 3 & 14.4 & 2 & 0.001 \\
MPI & 8 & 172.48 & 7 & 0.0 \\
PGD & 3 & 2.13 & 2 & 0.345 \\
GPI & 6 & 6.55 & 5 & 0.256 \\
PGM & 7 & 166.14 & 6 & 0.0 \\
& & 412.34 & 29 & 0.0 \\
\hline
\end{tabular}

DF: degrees of freedom

Lapinha - MG) display a certain degree of heterogeneity, but no disjunction pattern was observed that could suggest the existence of distinct populations. The heterogeneity became more evident when the union of the north/northeast populations (PA, MA, CE and RN) was performed. This new population proved to be disjunctive from that of Gruta da Lapinha (MG), based on 13 male and 19 female characters. This fact could suggest that the Gruta da Lapinha population is the most heterogeneous in relation to the other populations.

Mukhopadhyay et al. (1998), studying $L$. longipalpis from Northeast and Southeast Brazil, suggested L. longipalpis in Brazil as a single species. They used 15 enzymatic loci and observed short distances and absence of diagnostic loci.

The allozyme data showed that the four populations of L. longipalpis (PA, MA, RN and MG) analyzed should be considered members of the same biological species. No diagnostic locus was detected among the four populations studied, and the Nei's D levels were thus very low, ranging from 0.004 to 0.037 . These values are well within the range observed for comparisons between conspe- cific populations (Ayala 1983, Thorpe \& Sole-Cava 1994).

Gene flow levels among the four Brazilian populations $(\mathrm{Nm}=3.6)$ agree well with the values reported for other $L$. longipalpis populations from Costa Rica and Honduras ( $\mathrm{Nm}=3.6$ and 3.0, respectively, Mutebi et al. 1998).

However, the population structure analysis showed that the populations displayed a moderate $\left(\mathrm{F}_{\mathrm{ST}}=0.065\right)$ degree of genetic structuring (Wright 1978), confirming similar observations of a broader study in Brazil (Mutebi et al. 1999). The three northern populations (PA, MA and $\mathrm{RN}$ ) were clearly more similar, differing from Gruta da Lapinha in the Southern. Since the geographical distance between the two most separate northern populations, Salvaterra and Natal $(1.550 \mathrm{~km})$ is about the same as the distance between Natal and Gruta da Lapinha $(1.770 \mathrm{~km})$, it is unlikely that the differentiation patterns follow the isolation-bydistance model. On the other hand, despite these similar geographical distances, the three northern populations are situated in the latitudinal range between $0^{\circ}$ and $6^{\circ} \mathrm{S}$, while the Gruta da Lapinha population is located at $20^{\circ} \mathrm{S}$. This may suggest that the observed genetic structuring is a consequence of adaptation to different climatic conditions. Adaptation to different climatic and ecological conditions has been proposed to explain the differentiation between $L$. whitmani populations in Brazil (Ready et al. 1998).

The Gruta da Lapinha population (consisting exclusively of sand flies with one pale-spotted pattern) showed a significant heterozygote deficiency for two allozyme loci.

It is important to emphasize the close relationship between the results obtained from morphological, morphometric, and isoenzymatic analyses, showing a peculiar profile for the Gruta da Lapinha population as compared to the North/Northeast ones. The morphological and genetic differences noted between the North/Northeast (PA, MA, CE and $\mathrm{RN}$ ) and Gruta da Lapinha (MG) populations may result from a latitudinal or even altitudinal variation, since the analysis of other populations 
from the Brazilian plateau review a high similarity the Lapinha Cave population (Mutebi et al. 1999).

\section{ACKNOWLEDGMENTS}

To Dr José Wellington de Oliveira, Fundação Nacional de Saúde (FNS) from Fortaleza, CE, Arlinete S Medeiros, FNS from Natal, RN, Lucy MB Lamara, FNS from São Luís, MA, Dr Adelson A Souza, Instituto Evandro Chagas from Belém, PA and Dr Reginaldo P Brazil, Instituto René Rachou-Fiocruz, from Belo Horizonte, MG, from sand fly collections.

\section{REFERENCES}

Abe JM, Papavero N 1991. Teoria Intuitiva dos Conjuntos, Makron, McGraw-Hill, São Paulo, 266 pp.

Ayala JC 1983. Enzymes as taxonomic characters. In GS Oxford \& D Roliinson (eds), Protein Polymorphism Adaptative and Taxonomic Significance, Academic Press, London, p. 3-26.

Badaró R 1995. Changing epidemiology of leishmaniasis in Brazil. In Seminar on Tropical Diseases, Society and the Environment, TDR/SAREC, p. 97-101.

Bermudes H, Dedet JP, Falcão AL, Feliciangeli D, Ferro C, Galati EAB, Gomes EL, Herrero MV, Hervas D, Lebbe J, Morales A, Oguzuku E, Perez E, Rangel EF, Sherlock IA, Torrez M, Vignes R, Wolff M 1991. Proposition of a standard description for phlebotomine sand flies. Parassitologia 33: 127-135.

Dujardin JP, Tibayrenc M 1985. Study of 11 enzymes and formal genetic findings for 19 enzymatic loci in Triatoma infestans. Ann Soc Belg Med Trop 65: 27180.

Dujardin JP, Torrez EM, Le Pont F, Hervas D, Sossa D 1997. Isozymic and metric variation in the Lutzomyia longipalpis complex. Med Vet Entomol 1: 394-400.

Dyar HG, Nuñez-Tovar M 1926/27. Notes on biting flies from Venezuela. Insec Inscit Menst 14: 152156.

Fairchild GB, Hertig M 1958. Notes on the Phlebotomus of Panama. XV-Four apparently new synonymies. Proc Ent Soc Washington 60: 203-205.

Galliard H 1934. Un phlebotome nouveau de Yucatan, Phlebotomus almazani n. sp. An Parásit Hum Comp 12: 193-195.

Lane R, Ward RD 1984. The morphology and possible function of abdominal pacthes in males of the two forms of the leishmaniasis vector Lutzomyia longipalpis. Cah ORSTOM Ser Ent Med Parásit 22: 245-249.

Lane R, Phillips A, Molyneux DH, Procter C, Ward R 1985. Chemical analysis of the abdominal glands of two forms of the Lutzomyia longipalpis: site of a possible sex pheromone? Ann Trop Med Parasit 79: 225-229.

Lanzaro GC, Alexander B, Mutebi JP, Montoya-Lerma J, Warburg A 1998. Genetic variation among natural and laboratory colony populations of Lutzomyia longipalpis (Lutz \& Neiva, 1912) (Diptera: Psychodidae) from Colombia. Mem Inst Oswaldo Cruz 93:
65-69.

Lanzaro GC, Lopes AHCS, Ribeiro JMC, Shoemaker CB, Warburg A, Soares M, Titus RG 1999. Variation in the salivary peptide, maxadilan, from species in the Lutzomyia longipalpis complex. Insect Mol Biol 8: 267-275.

Lanzaro GC, Ostrovska K, Herrero MV, Lawyer PG, Warburg A 1993. Lutzomyia longipalpis is a species complex: genetic divergence and interspecific hybrid sterility among three populations. Am J Trop Med Hyg 48: 839-847.

Li CC, Horvitz DG 1953. Some methods of estimating the inbreeding coefficient. Am J Hum Genet 95: 107117.

Lutz A, Neiva A 1912. Contribuição para o conhecimento das espécies do gênero Phlebotomus existentes no Brasil. Mem Inst Oswaldo Cruz 4: 82-95.

Mangabeira Filho O 1969. Sôbre a sistemática e biologia dos Phlebotomus do Ceará. Rev Bras Malariol Doenc Trop 21: 3-26.

Mukhopadhyay J, Rangel EF, Ghosh K, Munstermann LE 1997. Patterns of genetic variability in colonized strains of Lutzomyia longipalpis (Diptera: Psychodidae) and its consequences. Am J Trop Med Hyg 57: 216-221.

Mukhopadhyay J, Ghosh K, Azevedo ACR, Rangel EF, Munstermann LE 1998. Genetic characterization of a natural population of Lutzomyia longipalpis (Diptera: Psychodidae) at an endemic area of visceral leishmaniasis in Natal, Northeast, Brasil. J Am Mosquito Control Assoc 14: 277-282

Munstermann LE, Morrison AC, Ferro C, Pardo RH, Torres M 1998. Genetic structure of local populations of Lutzomyia longipalpis (Diptera: Psychodidae) in Central Colombia. J Med Entomol 35: 8289.

Mutebi JP, Rowton E, Herrero MV, Ponce C, Belli A, Valle S, Lanzaro GC 1998. Genetic variability among populations of the sand fly, Lutzomyia (Lutzomyia) longipalpis (Diptera:Psychodidae) from Central America. J Med Entomol 35: 169-174.

Mutebi JP, Alexander B, Sherlock I, Wellington J, Souza AA, Shaw J, Rangel EF, Lanzaro GC 1999. Breeding structure of sand fly Lutzomyia longipalpis (Lutz \& Neiva) in Brazil. Am J Trop Med Hyg 61:149-157

Nei M 1977. F-statistics and analysis of gene diversity in subdivided populations. Ann Hum Genet 41: 225233.

Nei M 1978. Estimation of average heterozygosity and genetic distance from a small number of individuals. Genetics 89: 583-590.

Nuñez-Tovar M 1924. Mosquitos y Flebótomos. V Congress Venezuelano Medicina, 217-221 pp.

Ready PD, Souza AA, Rebelo JM, Day JC, Silveira FT, Campbell-Lendrum D, Davies CR, Costa JM 1998. Phylogenetic species and domesticity of Lutzomyia whitmani at the southeast boundary of Amazonian Brazil. Trans R Soc Trop Med Hyg 92: 159-160.

Rosa-Freitas MG, Deane LM, Momen H 1990. A morphological, isoenzymatic and behavioral study of ten populations of Anopheles (Nyssorhynchus) 
albitarsis Lynch-Anibalzaga, 1878 including from the type-locality, Baradero, Argentina. Mem Inst Oswaldo Cruz 85: 275-289.

Slatkin M 1987. Gene flow and the geographic structure of natural populations. Science 236: 787-792.

Swofford L, Selander RB 1981. BIOSYS - A computer program for the analysis of genetic variation in genetics. User' manual.

Thorpe JP, Sole-Cava AM 1994. The use of allozyme electrophoresis in invertebrate systematics. Zool Scr 23: $3-18$

Waples RS 1987. A multispecies approach to the analysis of gene flow in marine store fishes. Evolution 41: 385-400.

Warburg A, Saraiva E, Lanzaro GC, Titus R, Neva F 1994. Saliva of Lutzomyia longipalpis sibling species differs in its composition and propensity to enhance leishmaniasis. Phil Trans Roy Soc Load 345: 223-230.

Ward RD, Ribeiro AL, Ready PD, Murtagh A 1983. Reproductive isolation between different forms of Lutzomyia longipalpis (Lutz and Neiva), (Diptera:Psychodidae), the vector of Leishmania donovani chagasi Cunha and Chagas and its signifi- cance to kala-azar distribution in South America. Mem Inst Oswaldo Cruz 78: 269-280.

Ward RD, Ribeiro AL, Ryan L, Falcão AL, Rangel EF 1985. The distribution of two morphological forms of Lutzomyia longipalpis (Lutz and Neiva) (Diptera: Psychodidae). Mem Inst Oswaldo Cruz 80: 145-148.

Ward RD, Phillips A, Burnet B, Marcondes CB 1988. The Lutzomyia longipalpis complex: reproduction and distribution. In MW Service, Biosystematics of Haematophagus Insects, Oxford University Press, Oxford, p. 257-269.

Wright S 1978. Evolution and the Genetics of Populations. Variability within and among Natural Populations, 4. University of Chicago, Chicago, $580 \mathrm{pp}$.

Yin H, Mutebi JP, Marriott S, Lanzaro GC 1999. Metaphase karyotypes and G-banding in sandflies of the Lutzomyia longipalpis complex. Med Vet Entomol 13: 72-77.

Young DC, Duncan NA 1994. Guide to the identification and geographic distribution of Lutzomyia sandflies in México, the West Indies, Central and South America (Diptera: Psychodidae). Mem An Ent Inst 54: 1-881. 